\title{
Adverse events and other incidents in neonatal intensive care units
}

Luciana da Silva Lanzillotti ${ }^{1}$

Marismary Horsth De Seta ${ }^{2}$

Carla Lourenço Tavares de Andrade ${ }^{2}$

Walter Vieira Mendes Junior ${ }^{2}$

${ }^{1}$ Escola Nacional de Saúde Pública Sérgio Arouca, Fundação Oswaldo Cruz. R. Leopoldo Bulhões 1480, Manguinhos. 21041-210 Rio de Janeiro RJ Brasil. lucianasl@iff.fiocruz.br. ${ }^{2}$ Departamento de Administração e Planejamento em Saúde, Escola Nacional de Saúde Pública Sérgio Arouca, Fundação Oswaldo Cruz.
Abstract The occurrence of avoidable adverse events (AEs) represents a problem of quality of care that is responsible for the increase in monetary and social costs, causing suffering to the patient, their family members and the professional involved. This situation is aggravated when it involves newborns (NBs) with very low birth weights and shorter gestational ages, admitted to neonatal intensive care units (NICU). The scope of this study is to understand more about these incidents and adverse events in NICUs. The article aims to identify the occurrence of incidents, with and without injury that have occurred in NICUs in the literature and correlate this with the gestational age group of the NBs most affected. This is a systematic review of the available literature on incidents, particularly AEs as witnessed in NICUs. This study reveals that the types of incidents that occur in NICUs, with or without injury to the patient, are related to errors or failures in medication use, healthcare-associated infections (HAIs), skin injuries, mechanical ventilation and intravascular catheters. The cause of incidents and adverse events in NICUs are associated with human factors and the outcomes that are most damaging are due to HAIs. Furthermore, the study points out ways to mitigate these occurrences.

Key words Incidents, Adverse events, Neonatal intensive care unit 


\section{Introduction}

The health care process is not exempt from risk. Different degrees of injuries can often occur, even though the intention was to provide good care to the patient. Patients suffering from more serious clinical conditions, who have undergone multiple interventions, and who remain in hospital for longer periods, are more liable to suffer from the undesirable effects of the care offered ${ }^{1,2}$. These undesirable effects are known as incidents and are defined as being events or circumstances that could have outcomes, or can result in unnecessary injury to the patient, arising from non-intentional or intentional acts ${ }^{3}$.

These incidents can involve injuries to a patient, which are defined $s$ as adverse events (AEs), resulting from the intervention of a health team, rather than as a consequence of the patient's underlying condition per $\mathrm{s}^{3,5}$. Some AEs are the result of errors. Errors are understood to be the non-occurrence of a planned action (error in execution) or the implementation of a plan that went awry (planning error), and consist of avoidable adverse events ${ }^{3,4,6}$. Other AEs, not caused by errors, are not avoidable as, for example, injury to patients caused by medication that has been correctly prescribed and administered.

The occurrence of avoidable AEs represents a problem affecting the quality of healthcare, that is responsible for increasing financial and social costs, causes patients to suffer, as well as their families and the professional involved. AEs are an issue of international concern, and the World Health Organization (WHO) is seeking to develop methodologies for their detection. It is believed that the incidence of AEs varies between 2.9 to 16.6 in every patient admitted to hospital ${ }^{7}$.

This situation seems even more serious when involving newborns (NBs) with very low birth weights and a lower gestational age ${ }^{8}$, who are in a critical condition, and hospitalized in neonatal intensive care units $(\mathrm{NICU})^{9}$. In these units, a single patient, often a very premature newborn is handled by various professionals, which increases the likelihood of possible suffering caused by an error. A newborn like this undergoes different diagnostic and treatment interventions, and therefore remains in hospital for a longer period, which also exposes this patient to greater potential risks and dangers, when even a minor error committed by a professional can have devastating effects in the short and long-term.

A study conducted at a NICU in the United States showed incidents of this kind affected 74\% of patients in hospital. The most common incidents were: intravenous catheter infiltrations, healthcare-associated infections (HAIs), accidental extubation, intraventricular hemorrhages and skin breakdowns ${ }^{8}$. These situations are associated with prolonged hospital stays and injuries, often permanent. In Brazil, in a similar study conducted in Recife, $84 \%$ of newborns in NICUs had AEs. Thermoregulation and blood sugar level disorders were found to be the most common problems ${ }^{10}$.

The lack of research in relation to the occurrence of such incidents and, in particular, to $\mathrm{AE}$ occurrences in NICUs, and the relevance of these cases in relation to the quality of health care, make it necessary to investigate these facts. The aim of this article is to identify the occurrence of incidents, with and without injury at a NICU as described in available literature, in correlation to the gestational age group of the newborns most affected.

\section{Methodology}

This study involves a systematic review of literature about incidents, especially AEs that have occurred in NICUs. The main purpose of this study is to seek to identify what type of adverse events (AEs) have occurred in NICUs and are described in the current literature.

The inclusion criteria include studies about AEs in NICUs, published between January 1, 2001 and December 31, 2011, irrespective of language. The exclusion criteria include: studies where no abstracts are available, editorial reviews, letters, comments, opinion articles, non-systematic reviews, evaluation studies on interventions strategies to reduce AEs, and studies related to AEs based on a specific drug therapy.

The following international bibliographic databases were used: PubMed, Scopus, Lilacs, as well as the Thesis and Dissertation Databases at the Coordination for the improvement of Higher Education Personnel (CAPES), to find recent Brazilian academic production not yet published in indexed journals. References used in the selected articles, also served as a source of additional research data. The strategy used to research the bibliographic reference databases, with the exception of the specificity adaptations for each one, was as follows:

(adverse events OR medical errors $O R$ adverse effects $O R$ malpractice OR negligence OR professional misconduct $O R$ patient safety $O R$ treatment failures $O R$ diagnostic errors $O R$ iatrogenic disease 
$O R$ safety management $O R$ equipment failure $O R$ complications OR hazard management) AND NICUs (neonatal intensive care units).

EndNote Web $3.4^{\oplus}$ software was used as the bibliographic reference manager, helping to eliminate duplicates and to organize those that required further evaluation.

The study search and selection process was carried out by two reviewers, reaching a consensus in the case of conflicting articles. In the first phase, their search produced 578 texts, of which 116 duplicate studies were later discarded, leaving 462 texts. After a full text reading of their headings, inclusion and exclusion criteria were applied. From these, sixteen articles, two masters' dissertations and one doctorate dissertation were selected. The quality of the articles was assessed using the STROBE (Strengthening the Reporting of Observational Studies in Epidemiology) Initiative $^{11}$, in particular by using the instrument with an authorized translation ${ }^{12}$.

After this stage, each study contained in the bibliographic references of the nineteen selected articles was read, to ensure that all publication of interest were included in the research. Even so, no new ones were added. The 17.0 version of the SPSS (Statistical Package for Social Science) was used to make a statistical calculation of the frequency of incidents and AEs.

\section{Findings}

These studies were predominately written in English (13) followed by Portuguese (4) and Spanish (2). The highest number of publications were produced in Europe (7). This was followed by South America (5), North America (4) and Asia and Oceania (2 and 1). The USA and Brazil produced the highest number of studies (4 each).

The studies were classified into three categories: studies that were only about incidents related to the use of medication $(n=9)$, studies that were about incidents related to the use of medication and other forms of care unrelated to medication $(n=5)$, and incidents unrelated to medication $(\mathrm{n}=5)$.

It is worth highlighting that thirteen of these studies came from the PubMed databases, three from SCOPUS, three from the CAPES theses and dissertation and none from the Lilacs database.

Of the nineteen studies selected, fifteen were recent publications (between 2007 and 2011); which seems to indicate a growing interest in the subject. The prospective method $(52.6 \%)$ and the retrospective method $(47.4 \%)$ were used in this survey. The following data sources were used: medical records (42.1\%), voluntary incident reporting $(36.8 \%)$ and a mix of methodologies (21 $\%)$. The period during which these investigations were developed varied between: up to one year (64\%), and between one and six years (35.3\%). The studies involved incidents, errors in medication, iatrogenic events and AEs. All these definitions considered an $\mathrm{AE}$ as an injury caused by health care.

Chart 1 provides the detailed characteristics of these studies; the group studied were newborns hospitalized in NICUS (thirteen studies), and newborns hospitalized in other sectors, such as in an emergency unit, pediatric surgery ward, an intermediary unit and general hospital ward (six studies). Most of these studies used incident reporting as their data source, totaling 12.471 reports, of which 4.380 were AEs and 547 were described only as errors.

Studies showed that there was an average of fifteen beds in a NICU. Newborns (NBs) had an average gestational age of thirty-three weeks $( \pm$ 2,5 weeks, a minimum of twenty-eight weeks and a maximum of 35 weeks and five days) and the average weight of a newborn was $1786 \mathrm{~g}( \pm 444 \mathrm{~g}$, a minimum of $1080 \mathrm{~g}$ and maximum of $2411 \mathrm{~g}$ ).

Not only did these studies provide information about the types of NICU errors and incidents, these also showed the percentage of occurrences. This made it possible to analyze those that occurred more often, how frequently and how many studies were used to obtain these facts.

According to Table 1, the most common incidents in a NICU involve problems related to how medications are used, especially in respect to incorrect or inadequate dosages (with an average of $38 \%$ ). This is followed by cases of omission (an act when a prescribed medication is not administered or when no prescription is available for medication that is needed), wrong route administration and medication error. Other incidents include healthcare-associated infections (HAIs), skin lesions, mechanical ventilator problems (faulty extubation procedures and accidental extubation) and loss of vascular catheter.

\section{Discussion}

This study shows that the type of incidents that occur in a neonatal intensive care unit, with or without injury to a patient, involve errors or failures in the use of medication, HAIs, skin lesions, 
Chart 1. Detailed characteristics of studies analyzed.

\begin{tabular}{|c|c|c|c|c|c|}
\hline Author & Type of error & Cause of error & $\begin{array}{c}\text { Patient's final } \\
\text { outcome after error }\end{array}$ & $\begin{array}{l}\text { Error and AE risk } \\
\text { factor }\end{array}$ & Suggestions \\
\hline $\begin{array}{l}\text { Snijders, } \\
2011^{13}\end{array}$ & $\begin{array}{l}\text { Incorrect configurations } \\
\text { \& connections/ } \\
\text { unplanned removal/ } \\
\text { mechanical fault/ } \\
\text { occlusion/prolonged use }\end{array}$ & $\begin{array}{l}\text { Human error/ } \\
\text { technician/ } \\
\text { organizational/ } \\
\text { patient related }\end{array}$ & Minor damage & - & $\begin{array}{c}\text { Training/ongoing } \\
\text { education }\end{array}$ \\
\hline $\begin{array}{l}\text { Stavroudis, } \\
2010^{14}\end{array}$ & $\begin{array}{c}\text { Dosage, time, } \\
\text { prescription, } \\
\text { preparation, means } \\
\text { \& administration } \\
\text { technique \& incorrect } \\
\text { drug labeling/omission/ } \\
\text { expired products }\end{array}$ & $\begin{array}{l}\text { Human factors/ } \\
\text { devises/drug } \\
\text { labeling/ } \\
\text { confusion about } \\
\text { the dosage or } \\
\text { name/scarcity of } \\
\text { medication }\end{array}$ & $\begin{array}{l}\text { Longer hospital } \\
\text { stay/change of } \\
\text { therapy/increase } \\
\text { diagnostic tests/ } \\
\text { resuscitation }\end{array}$ & $\begin{array}{l}\text { High-alert } \\
\text { medications/ } \\
\text { prescriptions/ } \\
\text { medication } \\
\text { administration \& } \\
\text { dispensing devices } \\
\text { /monitoring }\end{array}$ & - \\
\hline $\begin{array}{c}\text { Barrionuevo, } \\
2010^{15}\end{array}$ & $\begin{array}{l}\text { Handling of catheters, } \\
\text { extubation, retinopathy } \\
\text { of prematurity, } \\
\text { hemorrhage \& } \\
\text { transfusions }\end{array}$ & - & $\begin{array}{c}\text { Half of the deaths } \\
\text { could probably have } \\
\text { been avoided }\end{array}$ & $\begin{array}{c}\text { Hospitalization \& time } \\
\text { spent in NICU, lower } \\
\text { gestational age and low } \\
\text { weight }\end{array}$ & - \\
\hline $\begin{array}{l}\text { Schuman, } \\
2010^{16}\end{array}$ & $\begin{array}{c}\text { Laryngopharyngeal } \\
\text { lesion }\end{array}$ & - & $\begin{array}{l}\text { Wide spectrum of } \\
\text { antibiotics/ } \\
\text { pediatric surgery/ } \\
\text { stop oral feeding }\end{array}$ & $\begin{array}{l}\text { Prematurity \& low } \\
\text { birth weight }\end{array}$ & - \\
\hline Jain, $2009^{17}$ & $\begin{array}{l}\text { Dose, time, infusion } \\
\text { rate, preparation } \\
\text { techniques \& wrong } \\
\text { administrations/ } \\
\text { omission/other }\end{array}$ & - & $\begin{array}{c}89 \% \text { were minor } \\
\text { and did not cause } \\
\text { damages }\end{array}$ & - & $\begin{array}{c}\text { Minimize errors in the } \\
\text { work place }\end{array}$ \\
\hline $\begin{array}{l}\text { Kunac, } \\
2009^{18}\end{array}$ & - & - & $\begin{array}{c}\text { Death/ } \\
\text { incapacity during } \\
\text { neonatal period/ } \\
\text { risk of life/ } \\
\text { hospitalization }\end{array}$ & $\begin{array}{l}\text { Highest rate of AEs in } \\
\text { NICU \& less time spent } \\
\text { in a post-natal hospital } \\
\text { ward }\end{array}$ & $\begin{array}{c}\text { Computerized system/ } \\
\text { incorporate } \\
\text { pharmacists/ } \\
\text { protocols for } \\
\text { medication }\end{array}$ \\
\hline $\begin{array}{l}\text { Pedrosa, } \\
2009^{19}\end{array}$ & $\begin{array}{l}\text { Non-infectious } \mathrm{AE} / \\
\text { related to a } \mathrm{MV}^{*} \text { and/ } \\
\text { or } \mathrm{CVC}^{* *} / \mathrm{Un} \text {-related } \\
\text { to other invasive } \\
\text { procedures }\end{array}$ & - & & $\begin{array}{l}\text { NBs with } \leq 1500 \mathrm{~g} / \\
\text { greater occurrence of } \\
\text { primary laboratory } \\
\text { septicemia }\end{array}$ & - \\
\hline
\end{tabular}

it continues

mechanical ventilators and intravascular catheters. This fact differs from the incident profile encountered in adult patient health care, where most AEs are described as being related to surgi- cal procedures, followed by medical procedures ${ }^{30}$ or by AEs associated with medication ${ }^{31}$.

This may be explained by the specific nature of neonatal intensive care treatment, which en- 


\begin{tabular}{|c|c|c|c|c|c|}
\hline \multicolumn{6}{|c|}{ Chart 1. continuation } \\
\hline Author & Type of error & Cause of error & $\begin{array}{c}\text { Patient's final } \\
\text { outcome after error }\end{array}$ & $\begin{array}{l}\text { Error and } \mathrm{AE} \\
\text { risk factor }\end{array}$ & Suggestions \\
\hline $\begin{array}{l}\text { Snijders, } \\
2009^{20}\end{array}$ & $\begin{array}{c}\text { Usage \& wrong connections/ } \\
\text { Unplanned removal/ harmful } \\
\text { \& unavailable materials/ } \\
\text { occlusion/ } \\
\text { prolonged use/Dose, rate } \\
\text { of infusion, time, patient \& } \\
\text { wrong route administration/ } \\
\text { overdue/tests not carried } \\
\text { out or unnecessary/delayed } \\
\text { results/material not received }\end{array}$ & 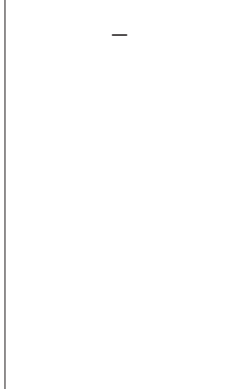 & - & $\begin{array}{l}\text { Use of } \mathrm{MV}^{*} \text {, blood- } \\
\text { based products, } \\
\text { intravascular \& } \\
\text { parenteral lines, } \\
\text { errors in nutritional \& } \\
\text { medication } \\
\text { dosages }\end{array}$ & - \\
\hline $\begin{array}{l}\text { Ventura, } \\
2009^{10}\end{array}$ & $\begin{array}{c}\text { Thermoregulation disorder } \\
\text { \& glycemia, hospital infection } \\
\text { and unplanned extubation, } \\
\text { unscheduled extubation }\end{array}$ & - & $\begin{array}{l}\text { Temporary } \\
\text { damages/ } \\
\text { More lengthy } \\
\text { hospital stay }\end{array}$ & $\begin{array}{l}\text { NBs with very low } \\
\text { weights }\end{array}$ & - \\
\hline $\begin{array}{l}\text { Lerner, } \\
2008^{21}\end{array}$ & $\begin{array}{l}\text { Medication error, omission \& } \\
\text { commission }\end{array}$ & - & - & $\begin{array}{c}\text { Incidents occur most } \\
\text { frequently during the } \\
\text { day, affecting very } \\
\text { premature NBs, with } \\
\text { very low birth weights \& } \\
\text { who have spent longer } \\
\text { periods in NICUs }\end{array}$ & $\begin{array}{l}\text { Provide training } \\
\text { for health } \\
\text { professionals \& } \\
\text { introduce a } \\
\text { culture of error } \\
\text { prevention }\end{array}$ \\
\hline $\begin{array}{l}\text { Kulgeman, } \\
2008^{22}\end{array}$ & $\begin{array}{l}\text { Nosocomial infection/ } \\
\text { medication errors, in } \\
\text { the respiratory system, } \\
\text { electrolytes in the } \\
\text { gastrointestinal system }\end{array}$ & - & $\begin{array}{l}\text { Potentially fatal, } \\
\text { significant \& } \\
\text { harmful }\end{array}$ & $\begin{array}{c}\text { Very premature NBs } \\
\text { with very low weights \& } \\
\text { who have spent longer } \\
\text { periods in hospital }\end{array}$ & $\begin{array}{c}\text { Map \& intervene } \\
\text { in every type of } \\
\text { error }\end{array}$ \\
\hline Ligi, $2008^{23}$ & $\begin{array}{l}\text { Cutaneous, nosocomial } \\
\text { infection, vascular, } \\
\text { respiratory, digestive \& } \\
\text { medication }\end{array}$ & $\begin{array}{l}\text { Infusion pump } \\
\text { programming } \\
\text { errors (most } \\
\text { common) }\end{array}$ & - & $\begin{array}{c}\text { Very premature NBs, } \\
\text { with very low birth } \\
\text { weights, use of } \mathrm{CVC}^{* *} \\
\& \mathrm{VM}^{*}\end{array}$ & $\begin{array}{c}\text { Create a safe } \\
\text { environment \& } \\
\text { analyze all events }\end{array}$ \\
\hline Hicks, $2007^{24}$ & $\begin{array}{c}\text { Dose, administration } \\
\text { technique, time, patient, drug } \\
\text { \& wrong route/omission/data } \\
\text { not supplied/expired product }\end{array}$ & $\begin{array}{c}\text { Improper use } \\
\text { of an infusion } \\
\text { pump, inadequate } \\
\text { execution, } \\
\text { protocol not used, } \\
\text { calculation \& } \\
\text { communication } \\
\text { error }\end{array}$ & 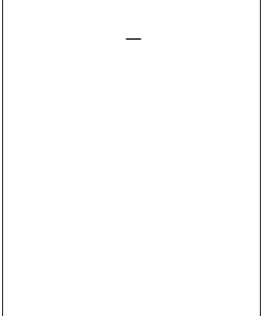 & $\begin{array}{l}\text { Administration phase. } \\
\text { Change of shifts/ } \\
\text { Distractions/ } \\
\text { increased workload }\end{array}$ & $\begin{array}{l}\text { Implement a plan } \\
\text { for the use of } \\
\text { medication }\end{array}$ \\
\hline
\end{tabular}

tails excessive handling by a multidisciplinary team and especially with respect to medication use. The preparation of medication to be administered to a patient requires a series of calculations to obtain the right dosage, which is adjusted on a daily basis according to the weight gain or loss, changes related to the metabolic maturity and excretory system of each patient $t^{5}$, as well as a rigorous adherence to a medication regimen and a narrow therapeutic margin ${ }^{32}$. The complex equa- 
Chart 1. continuation

\begin{tabular}{|c|c|c|c|c|c|}
\hline Author & Type of error & Cause of error & $\begin{array}{l}\text { Patient's final } \\
\text { outcome after error }\end{array}$ & $\begin{array}{l}\text { Error and AE risk } \\
\text { factor }\end{array}$ & Suggestions \\
\hline $\begin{array}{l}\text { Chedoe, } \\
2007^{27}\end{array}$ & $\begin{array}{l}\text { Wrong dosage (most } \\
\text { common occurrence) }\end{array}$ & $\begin{array}{l}\text { Wrong dosage, } \\
\text { units \& } \\
\text { calculations/ } \\
\text { wrong recorded } \\
\text { weight }\end{array}$ & - & $\begin{array}{c}\text { Intravenous } \\
\text { medication } \\
\text { contributes towards } \\
\text { errors involving } \\
\text { NBs }\end{array}$ & $\begin{array}{l}\text { Computerized requests/ } \\
\text { Integrate a clinical } \\
\text { pharmacist in the health } \\
\text { team }\end{array}$ \\
\hline $\begin{array}{l}\text { Ferreira, } \\
2007^{28}\end{array}$ & $\begin{array}{l}\text { Accidental loss of a CVC/ } \\
\text { laboratory \& clinical } \\
\text { septicemia/Intracranial } \\
\text { hemorrhage/ retinopathy } \\
\text { of prematurity/accidental } \\
\text { extubation \& others }\end{array}$ & - & $\begin{array}{c}\text { Intracranial } \\
\text { hemorrhage, } \\
\text { change of tracheal } \\
\text { tube \& laboratory } \\
\text { septicemia }\end{array}$ & $\begin{array}{l}\text { Very premature } \\
\text { NBs with very low } \\
\text { birth weights }\end{array}$ & $\begin{array}{l}\text { Ongoing training. } \\
\text { Employ alternative } \\
\text { methods }\end{array}$ \\
\hline $\begin{array}{l}\text { Sharek, } \\
2006^{8}\end{array}$ & $\begin{array}{l}\text { Nosocomial infection/ } \\
\text { abnormal cranial image/ } \\
\text { unplanned extubation } \\
\text { requiring reintubation/ } \\
\text { necrotizing entercolitis } \\
\text { hypertension/convulsions/ } \\
\text { death/acute kidney failure/ } \\
\text { respiratory arrest/ } \\
\text { hyperglycemia \& others }\end{array}$ & $\begin{array}{l}\text { Avoidable \& } \\
\text { other unrelated } \\
\text { events }\end{array}$ & - & $\begin{array}{c}\text { Low birth weight } \\
\text { \& lower gestational } \\
\text { age }\end{array}$ & $\begin{array}{l}\text { Control occurrences of } \\
\text { adverse events \& use } \\
\text { automated tool system }\end{array}$ \\
\hline $\begin{array}{l}\text { Campino } \\
\text { Villegas, } \\
2006^{29}\end{array}$ & $\begin{array}{l}\text { Faulty dose, prescription, } \\
\text { wrong route administration } \\
\text { of medication/faulty notes }\end{array}$ & - & - & $\begin{array}{l}\text { More errors occur } \\
\text { in a NICU than in } \\
\text { an Intermediary } \\
\text { Unit (IU) }\end{array}$ & $\begin{array}{l}\text { Take into account faulty } \\
\text { system errors and not } \\
\text { individual human errors }\end{array}$ \\
\hline $\begin{array}{c}\text { Simpson, } \\
2004^{30}\end{array}$ & $\begin{array}{l}\text { More common in } \\
\text { intravenous medication }\end{array}$ & $\begin{array}{l}\text { Bad prescription } \\
\text { \& medication } \\
\text { administration } \\
\text { problems }\end{array}$ & $\begin{array}{l}\text { Most common \& } \\
\text { less serious clinical } \\
\text { outcome }\end{array}$ & - & $\begin{array}{l}\text { Integrate a clinical } \\
\text { pharmacist in the } \\
\text { health team, monitor } \\
\text { medication use and } \\
\text { provide ongoing } \\
\text { training for the } \\
\text { healthcare team }\end{array}$ \\
\hline $\begin{array}{l}\text { Frey, } \\
2002^{31}\end{array}$ & $\begin{array}{l}\text { Dose, wrong route \& wrong } \\
\text { medication }\end{array}$ & $\begin{array}{c}\text { Calculation, } \\
\text { unit, labeling \& } \\
\text { dose/ } \\
\text { illegible } \\
\text { instructions/no } \\
\text { dose prescribed }\end{array}$ & $\begin{array}{l}\text { Most common \& } \\
\text { less serious clinical } \\
\text { outcome }\end{array}$ & $\begin{array}{l}\text { Use of dopamine, } \\
\text { midazolam, } \\
\text { fentanyl } \\
\text { pancuronio, } \\
\text { heparin, ketamine, } \\
50 \% \text { glucose \& } \\
\text { others }\end{array}$ & $\begin{array}{l}\text { Make changes that } \\
\text { involve all members of } \\
\text { the NICU teams. }\end{array}$ \\
\hline
\end{tabular}

${ }^{*} \mathrm{MV}$ - Mechanical Ventilation and ${ }^{* *} \mathrm{CVC}$ - Central Venous Catheter.

Source: prepared by the authors.

tions employed for dosage regimen calculations ${ }^{32}$, directly affect the performance of a great number of required drug manipulation procedures, such as calculating drug dilutions and fractions, and also involve peculiarities in the administration of the medication itself, such as the need to use infu- sion pumps, to ensure that the drugs themselves do not cause vascular lesions, among others.

Medication used in a NICU involves so many procedures, such that this could be one of the reasons why the current review found this to be the most common factor linked to incidents in four- 
teen of the nineteen studies researched. As can be seen in Table 1, there is a high rate of incorrect or inadequate drug dosages (with an average 38 $\%$ frequency in the studies), followed by omission, especially at the moment of administration, faulty technical administration and wrong route administration. Other studies ${ }^{33-35}$, indicate the same results, which means that medication error is the most frequent AE to occur in NICUs. When compared to the frequency occurrence in hospitalized adults, it can be seen that this event occurs eight times more often in a NICU ${ }^{36}$.

Environmental factors can also influence incidents involving medication use, which can be caused by using inappropriate lighting in the medication preparation area, as well as distractions and interruptions during the preparation process $^{37}$. Some studies have already described how such errors were reduced when the lighting in the preparation area was improved, and suggest that further research should be carried out to study these "small" details ${ }^{38}$.

Other incidents identified at NICUs confirm HAIs, which in the case of premature and low weight NBs, can predispose them to septicemia, due to their immaturity and vulnerability, especially given their relative immune deficiency (such as poor phagocytosis) $^{39}$. Infections during the neonatal period are responsible for 15 to 45 $\%$ of infant mortality and morbidity in most countries, associated not only with immune system deficiency, but also with the performance of invasive procedures ${ }^{40}$.
Incidents involving skin lesions are also a cause for concern in these patients, since these help to increase levels of heat and water loss, which encourages a water-electrolyte and thermal imbalance, as well as increasing caloric consumption to repair damaged tissue and, above all, increasing the risk of infection ${ }^{40}$.

Mechanical ventilation problems, such as faulty extubation procedures, accidental extubations and a lost vascular catheter not only increase the risk of infection ${ }^{40}$, but can also lead to other complications as well ${ }^{13}$.

The NB group most at risk are the very premature (with an average of thirty-three weeks) with the lowest birth weight (an average of $1.786 \mathrm{~g}$ ). The group at most risk from incidents is also the one that is most vulnerable to a series of adverse events, since they have a limited capacity to react to these errors ${ }^{5}$. Low birth weight occurs in cases of premature babies and/or intrauterine growth retardation and is related to nearly four million neonatal deaths worldwide every year, mostly in developing countries ${ }^{41}$.

In the great majority of cases, incidents involving the use of medications, mechanical ventilation and intravascular catheters, are due to human error. Furthermore, studies that deal with skin lesions and HAIs have not investigated why these incidents occur. This may be due to a breach of protocol, lack of support, incompetence and weak teamwork ${ }^{42}$.

The findings of one study suggested that nurses who work more than forty hours per

Table 1. Frequency and type of incident per study.

\begin{tabular}{|c|c|c|c|c|c|}
\hline \multirow[b]{2}{*}{ Type of incident } & \multirow[b]{2}{*}{$\begin{array}{l}\text { Number of } \\
\text { studies (\%) }\end{array}$} & \multirow[b]{2}{*}{ Average } & \multicolumn{3}{|c|}{$\%$ Frequency } \\
\hline & & & $\begin{array}{l}\text { Standard } \\
\text { deviation }\end{array}$ & Mínimun & Maximum \\
\hline \multicolumn{6}{|l|}{ Medication } \\
\hline Incorrect/inadequate dosage & $8(42.0 \%)$ & 38.3 & 28.5 & 11.8 & 89.9 \\
\hline Omission & $6(31.6 \%)$ & 11.1 & 7.4 & 2.5 & 21.7 \\
\hline Faulty administration technique & $4(21.0 \%)$ & 9.5 & 6.3 & 2.5 & 14.8 \\
\hline Wrong route administration & $4(21.0 \%)$ & 7.1 & 7.0 & 0.4 & 13.4 \\
\hline IAHC & $6(31.5 \%)$ & 20.2 & 9.2 & 8.7 & 32.8 \\
\hline Skin lesions & $4(21.0 \%)$ & 21.0 & 17.1 & 0.4 & 35.2 \\
\hline \multicolumn{6}{|l|}{ Mechanical ventilation } \\
\hline Faulty extubation & $6(31.5 \%)$ & 12.9 & 9.7 & 3.5 & 29.1 \\
\hline Accidental extubation & $2(10.5 \%)$ & 8.5 & 8.9 & 2.2 & 14.9 \\
\hline \multicolumn{6}{|l|}{ Intravascular catheter } \\
\hline Accidental Loss & $3(15.8 \%)$ & 24.9 & 20.7 & 10.3 & 39.6 \\
\hline
\end{tabular}

Source: Prepared by the authors. 
week have a greater probability of occasionally or frequently witnessing or experiencing an adverse event, particularly those involving drug dosage administration $^{43}$.

Most of the incidents related to the use of medication affect the patient, but do not cause damage or are regarding as being less serious. Those related to mechanical ventilators and intravascular catheters cause minor injuries or only have temporary after-effects, with no risk of death. However, those resulting from HAIs increase the risk of temporary damage and/or prolong the time a patient has to stay in hospital.

Infection is recognized as an avoidable adverse event resulting from failures at different levels of healthcare. It is therefore essential that the healthcare team is made aware of their responsibilities so that they will be motivated to bring about change ${ }^{44}$.

Automated tools can be used to identify adverse events in real time (e.g. laboratory test results). In one study, the use of electronic prescriptions actually reduced medication errors and adverse events by up to $80 \%{ }^{45}$. The use of bar codes for drugs is another possibility to guarantee that the medication dispensed is the same one that was prescribed to a particular patient ${ }^{46}$.

One study that used a computerized medical system showed that fewer drugs were being administered at the wrong times, while also eliminating errors related to unspecified routes of $\operatorname{administration}^{47}$.

Based on the incidents and adverse events described, most of the studies recommend that continual training and education be given to teams involved in caring for NBs, together with computerized medical systems (as a preventative strategy $)^{36}$.

In order to promote safety in medication use and in the whole process of healthcare, further thought should be given to understanding the human factors involved in the use of technologies and in the control of environmental conditions. One way to help ensure patient safety when using medication is to use the "five rights": right patient, right drug, right dose, right time and right route ${ }^{37}$. Others could be incorporated into healthcare, including giving a patient accurate information about his/her treatment (sixth right $)^{48}$, the right of a patient to refuse medication (seventh right) ${ }^{49}$ and accurate annotation (eighth right $)^{50}$. Another way is to include a clinical pharmacist in the health team (in one study such an initiative prevented $58 \%$ of all errors $)^{50}$, introduce special protocols and change people's attitudes regarding the blame culture. Teamwork should operate within a "safety culture", which provides guarantees in cases of human falibility ${ }^{5}$, since part of the errors are related to complex processes, equipment, fragmented healthcare, communication problems and a lack of standardization $^{37}$.

The PubMed database was responsible for selecting $68.4 \%$ of the studies included in this review, which confirmed the findings of other studies related to patient safety ${ }^{6}$.

\section{Conclusions}

This study shows that the most common incidents that occur in a NICU involve the use of medication, and that the group most affected is also the most vulnerable, namely premature and low-weight NBs. This survey also underlines other questions of special interest, such as the fact that incidents and adverse events are associated with human factors and that the most harmful after-effects suffered by NBs, are caused by HAIs

The findings of this report can also show ways to alleviate such occurrences, for example by training healthcare teams and implementing a computerized system for prescription and diagnostic procedures.

Another factor of similar importance is that lessons should be learned from past failings. Analyzing failures should become part of the routine of the 'Grand rounds' (multidisciplinary meetings), as one of the foundations for implementing a safe health system.

Some of the first steps that can help to understand these occurrences would be to use the same strategy employed by this research study, evaluating incidents in accordance with their origin; factors that may have contributed towards this occurrence; the patient's outcome and suggesting ways these could have been prevented.

Among the incidents and events that take place in NICUs, problems related to the use of medication should be highlighted in particular, because these occur so frequently, as well as HAIs because of the damage that these can cause. Bearing these facts in mind, it is worth understanding and reviewing all procedures that can cause these types of occurrences in order to prevent these from occurring in the future, which will help improve the standards of healthcare for newborns (NBs). 


\section{Collaborations}

LS Lanzillotti worked on the concept of the article, methodology, search and selection of studies, analysis of the results, discussions, conclusion and preparation of charts and tables. MH de Seta worked on the methodology, search and selection of articles, analysis of the results and text revision. CLT Andrade worked on the search and selection of studies and text revision. WV Mendes Júnior worked on analysis of the results, discussion, conclusion and text revision.

\section{References}

1. Weingart SN, Wilson RMcL, Gibberd RW, Harrison B. Epidemiology of medical error. BMJ 2000; 320(7237):774-777.

2. Reis CT, Martins M, Laguardia J. A segurança do paciente como dimensão da qualidade do cuidado de saúde - um olhar sobre a literatura. Cien Saude Colet 2013; 18(7):2029-2036.

3. Institute of Medicine Committee on Quality Health Care in America. To Err Is Human: Building a Safer Health System. Washington: National Academy Press; 2000.

4. Leape LL, Brennan TA, Laird NM, Hebert L, Localio AR, Lawthers AG, Newhouse JP, Weiler PC, Hiatt HH. Incidence of adverse events and negligence in hospitalized patients: Results of the Harvard Medical Practice Study I. N Engl J Med 1991; 324(6):370-376.

5. Suresh GK. MEAuring Patient Safety in Neonatology. Am J Perinatol 2012; 29(1):19-26.

6. Mendes W, Travassos C, Mônica M, Noronha JC. Revisão dos estudos de avaliação da ocorrência de eventos adversos em hospitais. Rev Bras Epidemiol 2005; 8(4):393-406.

7. Gray JE, Goldmann DA. Medication errors in the neonatal intensive care unit: Special patients, unique issues. Arch Dis Child Fetal Neonatal Ed 2004; 89(6):472-473.

8. Sharek PJ, Horbar JD, Mason W, Bisarya H, Thurm CW, Suresh G, Gray JE, Edwards WH, Goldmann D, Classen D. Adverse events in the neonatal intensive care unit: development, testing, and findings of an NICUfocused trigger tool to identify harm in North American NICUs. Pediatrics 2006; 118(4):1332-1340.

9. Martins CD, Rego S. Bioética clínica: contribuições para a tomada de decisões em unidades de terapia intensiva neonatais. Cien Saude Colet 2008; 13(Supl. 2):2239-2246.

10. Ventura CMU. Eventos Adversos em Recém-Nascidos Admitidos na Unidade de Terapia Intensiva Neonatal do Instituto de Medicina Integral Prof. Fernando Figueira -Imip [dissertação]. Recife: Instituto de Medicina Integral Prof. Fernando Figueira; 2009.
11. Ebrahim S, Clarke M. STROBE: new standards for reporting observational epidemiology, a chance to improve. Int J Epidemiol 2007; 36(5):946-948.

12. Malta M, Cardoso LO, Bastos FI, Monica Maria Ferreira Magnanini MMF, Silva CMFP. Iniciativa STROBE: subsídios para a comunicação de estudos observacionais. Rev Saude Publica 2010; 44(3):559-565.

13. Snijders C, Lingen RA, Schaaf TW, Fetter WP, Molendijk HA. Incidents associated with mechanical ventilation and intravascular catheters in neonatal intensive care: exploration of the causes, severity and methods for prevention. Arch Dis Child Fetal Neonatal Ed 2011; 96(2):F121-126.

14. Stavroudis TA, Shore AD, Morlock L, Hicks RW, Bundy D, Mille MR. NICU medication errors: identifying a risk profile for medication errors in the neonatal intensive care unit. J Perinatol 2010; 30(7):459-468.

15. Barrionuevo L, Esandi ME. Epidemiología de eventos adversos en el servicio de neonatología de un hospital público regional en la Argentina. Arch Argent Pediatr 2010; 108(4):303-310.

16. Schuman TA, Jacobs B, Walsh W, Goudy SL. Iatrogenic perinatal pharyngoesophageal injury: A disEAe of prematurity. Int J Pediatr Otorhinolaryngol 2010; 74(4):393-397.

17. Jain S, Srikanta B, Veena RP. Medication errors in neonates admitted in intensive care unit and emergency department. Indian J Med Sci 2009; 63(4):393-397.

18. Kunac DL, Kennedy J, Austin N, Reith D. Incidence, preventability, and impact of adverse drug events (ADEs) and potential ADEs in hospitalized children in New Zealand: A prospective observational cohort study. Pediatr Drugs 2009; 11(2):153-160.

19. Pedrosa TMG. Erros e eventos adversos não infecciosos relacionados à assistência em terapia intensiva neonatal: epidemiologia e sua associação com a sepse primária laboratorial [tese]. Belo Horizonte: Universidade Federal de Minas; 2009. 
20. Snijders C, Lingen RA, Klip H, Fetter WPF, Schaaf TW, Molendijk HA. Specialty-based, voluntary incident reporting in neonatal intensive care: description of 4846 incident reports. Arch Dis Child Fetal Neonatal Ed 2009; 94(3):210-215.

21. Lerner RBME, Carvalho M, Vieira AA, Lopes JMA, Moreira MEL. Erros medicamentosos em unidade de terapia intensiva neonatal. J Pediatr 2008; 84(2):166-170.

22. Kugelman A, Inbar-Sanado E, Shinwell ES, Makhoul IR, Leshem M, Zangen S, Wattenberg O, Kaplan T, Riskin A, Bader D. Iatrogenesis in Neonatal Intensive Care Units: Observational and Interventional, Prospective, Multicenter Study. Pediatrics 2008; 122(3):550-555.

23. Ligi I, Arnaud F, Jouve E, Tardieu S, Sambuc R, Simeoni U. Iatrogenic events in admitted neonates: a prospective cohort study. Lancet 2008; 371(9610):404-410.

24. Hicks RW, Becker SC, Chuo J. A Summary of NICU Fat Emulsion Medication Errors and Nursing Services. $A d v$ Neonatal Care 2007; 7(6):299-310.

25. Mendes W, Travassos C, Martins M, Rozenfeld S. The assessment of adverse events in hospitals in Brazil. Int $J$ Qual Health Care 2009; 21(4):279-284.

26. Baker GR, Norton PG, Flintoft V, Blais R, Brown A, Cox J, Etchells E, Ghali WA, Hébert P, Majumdar SR, O’Beirne M, Palacios-Derflingher L, Reid RJ, Sheps S, Tamblyn R. The Canadian Adverse Events Study: the incidence of adverse events among hospital patients in Canada. CMAJ 2004; 170(11):1678-1686.

27. Chedoe I, Molendijk HA, Jansman FG, Harting JW. Incidence and nature of medication errors in neonatal intensive care with strategies to improve safety: a review of the current literature. Drug Safety 2007; 30(6):503513.

28. Ferreira VR. Análise dos eventos adversos em uma unidade de terapia intensiva neonatal como ferramenta de gestão da qualidade da assistência de enfermagem [dissertação]. Belo Horizonte: Universidade Federal de Minas Gerais; 2007.

29. Campino Villegas A1, López Herrera MC, García Franco M, López de Heredia Goya I, Valls i Soler A. Errores en la prescripción y transcripción de medicación en una unidad neonatal. An Pediatr (Barc) 2006; 64(4):330-335.

30. Simpson JH, Grant J, Alroomi L. Reducing medication errors in the neonatal intensive care unit. Arch Dis Child Fetal Neonatal Ed 2004; 89(6):480-482.

31. Frey B, Buettiker V, Hug MI, Waldvogel K, Gessler P, Ghelfi D, Hodler C, Baenziger O. Does critical incident reporting contribute to medication error prevention? Eur J Pediatr 2002; 161(11):594-599.

32. Kaushal R, Bates DW, Landrigan C, McKenna KJ, Clapp MD, Federico F, Goldmann DA. Medication errors and adverse drug events in pediatric inpatients. JAMA 2004; 285(16):2114-2120.

33. Murff HJ, Patel VL, Hripcsak G, Bates DW. Detecting adverse events for patient safety research: a review of current methodologies. J Biomed Inform 2003; 36(12):131-43.

34. Suresh G, Horbar JD, Plsek P, Gray J, Edwards WH, Shiono PH, Ursprung R, Nickerson J, Lucey JF, Goldmann D. Voluntary anonymous reporting of medical errors for neonatal intensive care. Pediatrics 2004; 113(6):1609-1618.
35. Morimoto T, Gandhi T, Seger A, Hsieh T, Bates D. Adverse drug events and medication errors: detection and classification methods. Qual Saf Health Care 2004; 13(4):306-314.

36. Simons SL. Designing Medication Safety in the NICU. Neonatal Netw 2007; 26(6):407-408.

37. Simpson J, Lynch R, Grant J, Alroomi L. How can we reduce medication errors in the neonatal intensive care unit? Br J Intensive Care 2007; 89(6):480-482.

38. Ulrich R. The role of the physical environment in the hospital of the 21st century: A once-in-a-lifetime opportunity. Princeton: Center for Health Design; 2005.

39. Buchanan TL, Barker KN, Gibson JT, Jiang BC, Pearson RE. Illumination and errors in dispensing. Am J Hosp Pharm 1991; 48(10):2137-2145.

40. Tames RN, Silva MJP. Enfermagem na UTI neonatal: assistência ao recém-nascido de alto risco. Rio de Janeiro: Ed. Guanabara Koogan; 2009.

41. Lawn JE, Cousens S, Zupan J. Lancet Neonatal Survival Steering Team. 4 million neonatal deaths: When? Where? Why? Lancet 2005; 365(9462):891-900.

42. Makhoul IR, Sujov P, Smolkin T, Lusky A, Reichman B. Epidemiological, clinical, and microbiological characteristics of late-onset sepsis among very low birth weight infants in Israel: a national survey. Pediatrics 2002; 109:34-39.

43. Simond SL. Using CUS Words in the NICU. Neonatal Netw 2008; 27(6):423-424.

44. Olds DM, Clarke SP. The Effect of Work Hours on Adverse Events and Errors in Health Care. J Safety Research 2010; 41(2):153-162.

45. Powers RJ, Wirtschafter DW. DecrEAing Central Line Associated Bloodstream Infection in Neonatal Intensive Care. Clin Perinatol 2010; 37(1):247-272.

46. Bates DW. Using information technology to reduce rates of medication errors in hospitals. BMJ 2000; 320(7237):788-791.

47. Carvalho M, Vieira A. Erro médico em pacientes hospitalizados. Jornal de Pediatria 2002; 78(4):261-268.

48. Fortescue EB, Kaushal R, Landrigan CP, McKenna KJ, Clapp MD, Federico F, Goldmann DA, Bates DW. Prioritizing strategies for preventing medication errors and adverse drug events in pediatric inpatients. Pediatrics 2003; 111(4 Pt 1):722-729.

49. Peterline MAS. Incompatibilidade no preparo e administração de terapia intravenosa em crianças: associação entre fármacos, soluções e materiais dos cateteres e acessórios [tese]. São Paulo: Universidade Federal de São Paulo; 2003.

50. Taylor JA, Loan LA, Kamara J, Blackburn S, Whitney D. Medication Administration Variances Before and After Implementation of Computerized Physician Order Entry in a Neonatal Intensive Care Unit. Pediatrics 2008; 121(1):123-128.

Article presented on 12/09/2013

Approved on 20/11/2013

Final version presented on 25/11/2013 